Prospects for

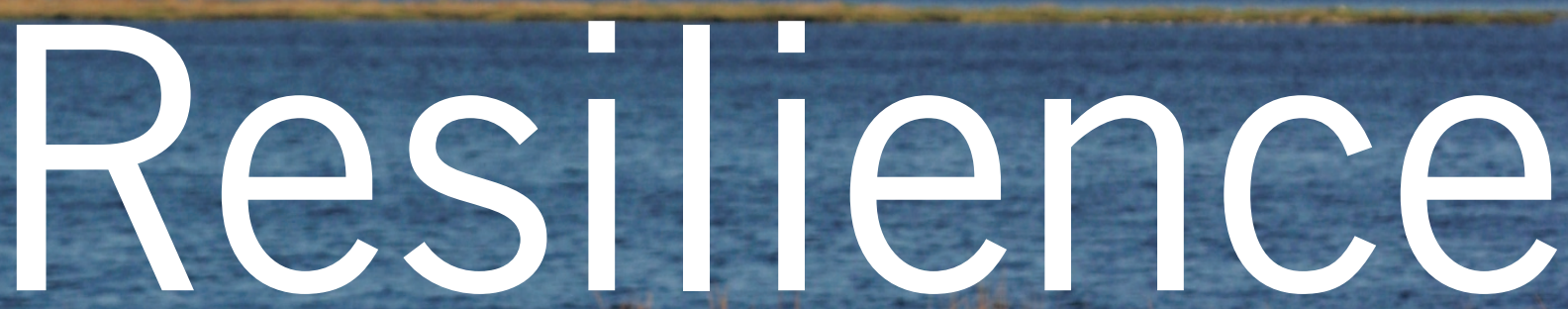

INSIGHTS FROM NEW YORK CITY'S JAMAICA BAY

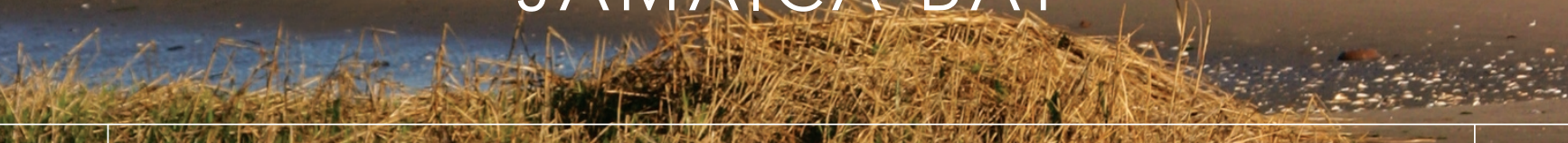
7.

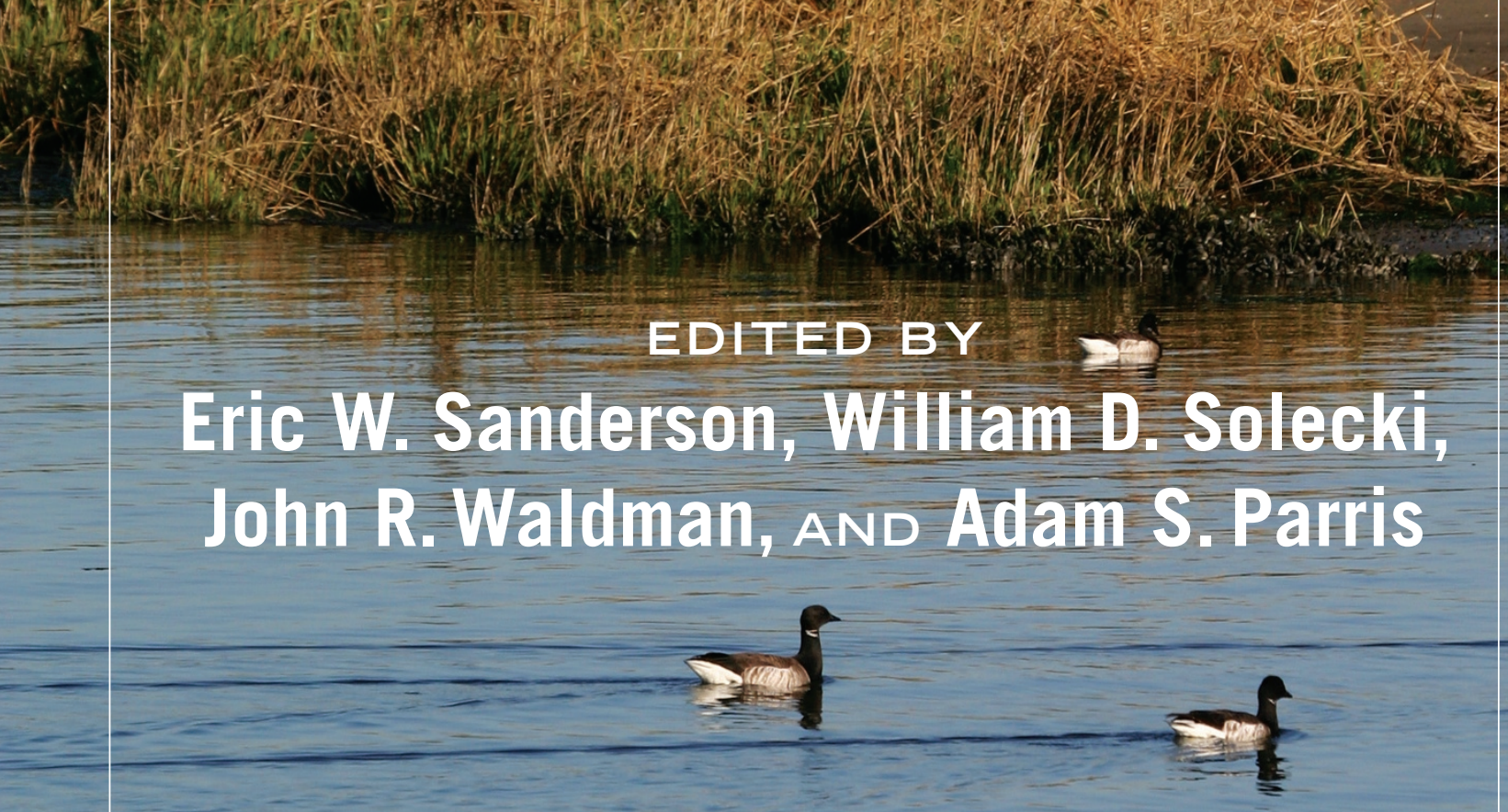





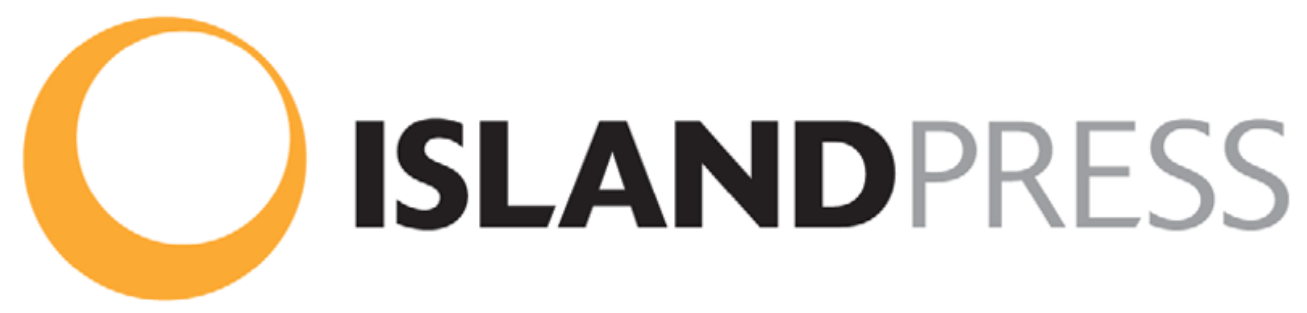

Island Press' mission is to provide the best ideas and information to those seeking to understand and protect the environment and create solutions to its complex problems. Join our newsletter to get the latest news on authors, events, and free book giveaways. Click here to join now! 


\section{Prospects for Resilience}

Eric W. Sanderson, William D. Solecki, John R. Waldman, and Adam S. Parris 



\section{Prospects for Resilience: Insights from New York City's Jamaica Bay}

Eric W. Sanderson, William D. Solecki, John R. Waldman, and Adam S. Parris 
Copyright @ 2016 Eric W. Sanderson, William D. Solecki, John R. Waldman, and Adam S. Parris All rights reserved under International and Pan-American Copyright Conventions. No part of this book may be reproduced in any form or by any means without permission in writing from the publisher: Island Press, 2000 M St. NW, Suite 650, Washington, DC 20036

Island Press is a trademark of The Center for Resource Economics.

Keywords: Adaptive management, Biodiversity, Coastal flooding, Climate change, Combined sewer overflow, Community resilience, Computer modeling, Decision science, Disturbance, Ecological history, Estuary, Equity, Gateway National Recreation Area, Governance, Green infrastructure, Greenstreets, Hazard, Hurricane Sandy, Jamaica Bay, Monitoring, New York City, Open-source models, Panarchy, Resilience, Science and Resilience Institute at Jamaica Bay, Self-advocacy, Social-ecological system, Stakeholder input, Visionmaker model, Watershed

Library of Congress Control Number: 2016938769

(3) Printed on recycled, acid-free paper

Manufactured in the United States of America

$\begin{array}{llllllllll}10 & 9 & 8 & 7 & 6 & 5 & 4 & 3 & 2 & 1\end{array}$ 


\section{Contents}

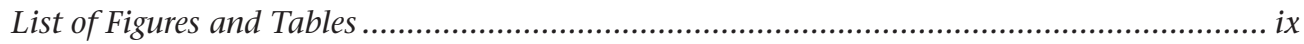

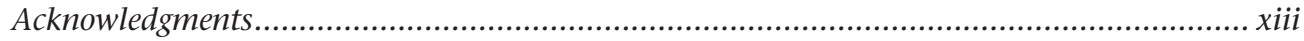

PART I: INTRODUCTION TO RESILIENCE IN JAMAICA BAY ........................................ 1

Chapter 1: Why Prospects for Resilience in Jamaica Bay? ............................................... 3

William D. Solecki, Eric W. Sanderson, John R. Waldman, and Adam S. Parris

Chapter 2: Resilience Practice in Urban Watersheds

Brett Branco and John R. Waldman

Chapter 3: Social-Ecological System Transformation in Jamaica Bay

Shorna Allred, Bryce DuBois, Katherine Bunting-Howarth, Keith Tidball, and William D. Solecki

PART II: SOCIAL-ECOLOGICAL SYSTEMS OF JAMAICA BAY

Chapter 4: Dynamics of the Biophysical Systems of Jamaica Bay 65

Larry Swanson, Michael Dorsch, Mario Giampieri, Philip Orton, Adam S. Parris, and Eric W. Sanderson

Chapter 5: Ecology of Jamaica Bay: History, Status, and Resilience

Steven N. Handel, John Marra, Christina M. K. Kaunzinger, V. Monica Bricelj, Joanna Burger, Russell L. Burke, Merry Camhi, Christina P. Colón, Olaf P. Jensen, Jake LaBelle, Howard C. Rosenbaum, Eric W. Sanderson, Matthew D. Schlesinger, John R. Waldman, and Chester B. Zarnoch

Chapter 6: Neighborhood and Community Perspectives of Resilience in the Jamaica Bay Watershed

Laxmi Ramasubramanian, Mike Menser, Erin Rieser, Mia Brezin, Leah Feder, Racquel Forrester, Shorna Allred, Gretchen Ferenz, Jennifer Bolstad, Walter Meyer, and Keith Tidball 
PART III: TOOLS FOR RESILIENCE PRACTICE

Chapter 7: Resilience Indicators and Monitoring: An Example of Climate Change Resiliency Indicators for Jamaica Bay

Bernice Rosenzweig, Arnold L. Gordon, John Marra, Robert Chant, Christopher J. Zappa, and Adam S. Parris

Chapter 8: Computational Modeling of the Jamaica Bay System 167

Eric W. Sanderson, Philip Orton, Jordan R. Fischbach, Debra Knopman, Hugh Roberts, William D. Solecki, and Robert Wilson

Chapter 9: Green Infrastructure as Climate Change Resiliency Strategy in Jamaica Bay 193

Maria Raquel Catalano de Sousa, Stephanie Miller, Michael Dorsch, and Franco A. Montalto

Chapter 10: Application of Decision Science to Resilience Management in Jamaica Bay

Mitchell J. Eaton, Angela K. Fuller, Fred A. Johnson, Matthew P. Hare, and Richard C. Stedman

PART IV: PROSPECTS FOR RESILIENCE IN JAMAICA BAY.

Chapter 11: Strategies for Community Resilience Practice for the Jamaica Bay Watershed

Laxmi Ramasubramanian, Mike Menser, Erin Rieser, Leah Feder, Racquel Forrester, Robin Leichenko, Shorna Allred, Gretchen Ferenz, Mia Brezin, Jennifer Bolstad, Walter Meyer, and Keith Tidball

Chapter 12: The Future of Jamaica Bay: Putting Resilience into Practice..... 253

Adam S. Parris, William D. Solecki, Eric W. Sanderson, and John R. Waldman

Contributor Biographical Sketches 263

Index 


\section{List of Figures and Tables}

\section{FIGURES}

Color plate I. Jamaica Bay, c. 1609.

Color plate II. Jamaica Sound, c. 1679.

Color plate III. Jamaica Bay, c. 1844.

Color plate IV. Concept for Jamaica Bay improvement, c. 1912.

Color plate V. Jamaica Bay, c. 2014.

Color plate VI. Map of land cover and water depths of the Jamaica Bay watershed.

Color plate VII. Map of selected jurisdictions in the Jamaica Bay watershed.

Color plate VIII. Map of population density and race in Jamaica Bay communities.

Figure 1-1. Hurricane Sandy, October 29, 2012 .............................................................. 4

Figure 1-2. Fire and storm damage at Breezy Point, New York......................................... 6

Figure 1-3. A view of Jamaica Bay ................................................................................ 7

Figure 1-4. A schematic of a nested social-ecological system (SES) ................................ 9

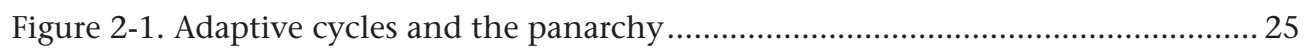

Figure 4-1. The current topography and bathymetry of the Jamaica Bay watershed ...... 66

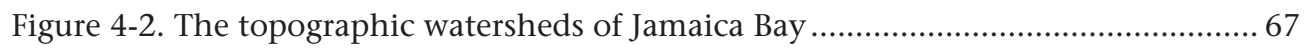

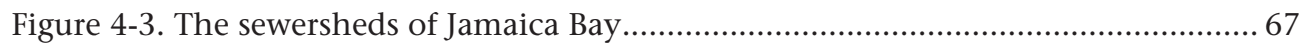

Figure 4-4. The Rockaway Peninsula advances, 1844-1907 ........................................... 71

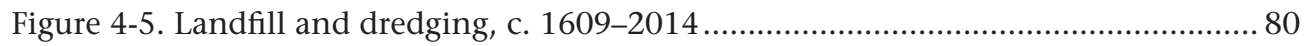

Figure 4-6. Sea level rise at the Battery, 1900-2014, with predictions for the future ...... 82

Figure 5-1. An American horseshoe crab (Limulus polyphemus) ................................. 97

Figure 5-2. Two people (Homo sapiens) sampling for fish in Jamaica Bay ........................ 99

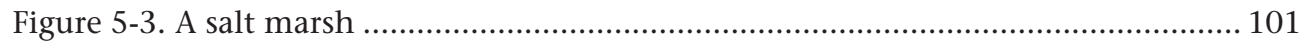

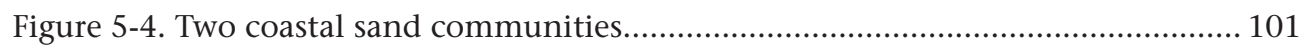

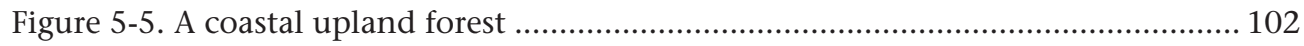

Figure 5-6. Marsh loss and restoration on Jamaica Bay islands, 1951-2008.................. 103

Figure 5-7. A coastal upland town ............................................................................ 104 
Figure 5-8. Great egrets (Ardea alba) and black-crowned night herons

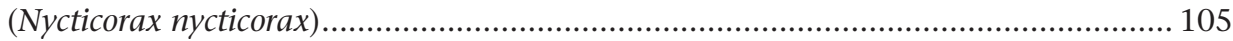

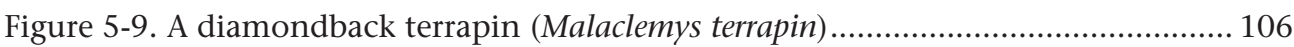

Figure 5-10. A hairy-necked tiger beetle (Cicindela hirticollis) ..................................... 107

Figure 6-1. Extent of flooding in Jamaica Bay communities caused by the storm

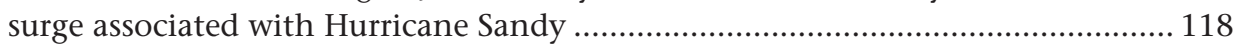

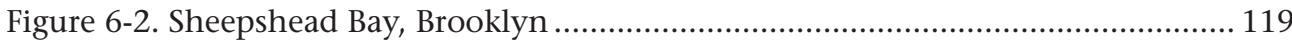

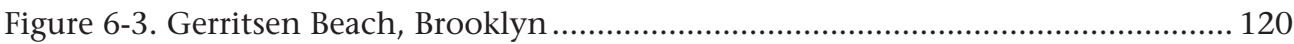

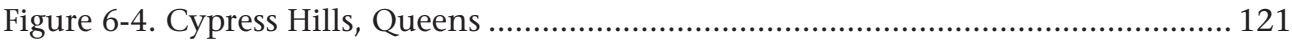

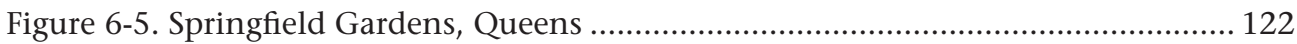

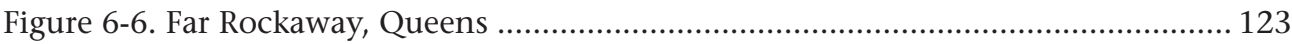

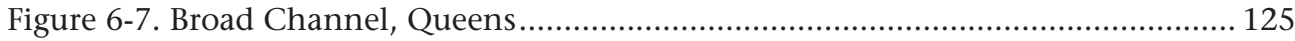

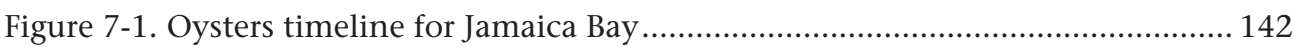

Figure 7-2. Selected hydrological, oceanographic, and water quality

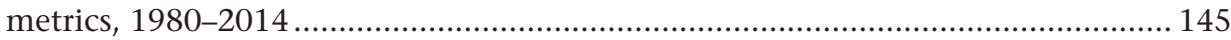

Figure 7-3. Extreme weather events and seasonally averaged hydrological,

oceanographic, and water quality metrics, 1980-2014 .......................................... 146

Figure 7-4. Water level at the Inwood tidal gauge during Hurricane Sandy,

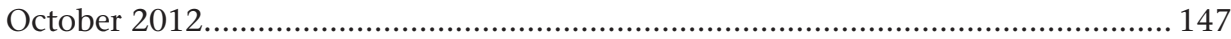

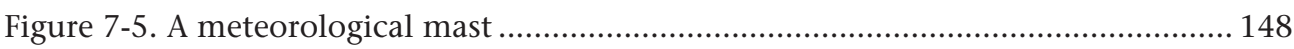

Figure 7-6. Weather measurements made at Jamaica Bay, February 6-16, 2016 ........... 149

Figure 7-7. Jamaica Bay temperature to salinity relationships for June through

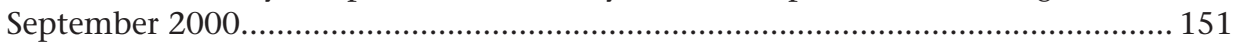

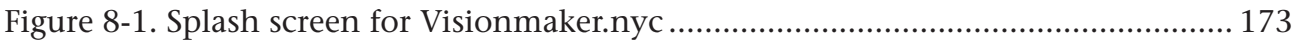

Figure 8-2. Visionmaker provides tools to create visions .......................................... 173

Figure 8-3. Visionmaker reports metrics of the water and carbon cycles,

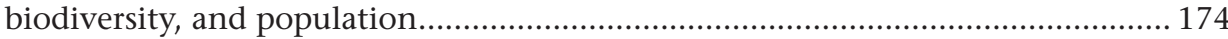

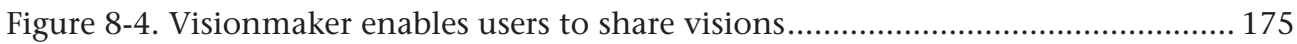

Figure 8-5. Simulation of Hurricane Sandy flooding................................................... 179

Figure 8-6. Simulation of sediment concentration at low water................................... 180

Figure 9-1: A conceptual model of urban ecosystem resilience to climate change ....... 194

Figure 9-2: A "greenstreet" designed to capture stormwater in Queens ........................ 199

Figure 9-3: Hydrologic performance of the Nashville Boulevard Greenstreet

during Hurricanes Irene and Sandy ....................................................................... 208

Figure 10-1. Components of a decision-analytic approach.......................................... 221

Figure 10-2. Hierarchical levels of learning in a triple-loop learning cycle ................... 223

Figure 11-1. Baby's Dream, Sheepshead Bay, Brooklyn ............................................. 242

Figure 11-2. Jamaica Bay, looking west toward Manhattan ....................................... 247

Figure 12-1. Governance and partnership framework for the Science and

Resilience Institute at Jamaica Bay (SRIJB) …...................................................... 256

Figure 12-2. Trail through the tangled woods near Jamaica Bay .................................. 258

Figure 12-3. Ospreys nest in sight of houses and high rises in New York City's

Jamaica Bay 


\section{TABLES}

Table 1-1. Annual number of visits at the Jamaica Bay units of the Gateway National Recreation Area in 2015, with comparison to other national parks ......................... 11

Table 1-2. A partial list of public agencies with responsibility for Jamaica Bay............... 14

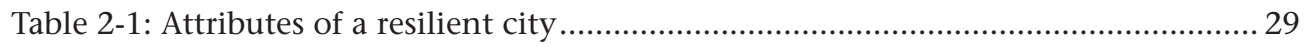

Table 2-2: Selected ecosystem services provided by Jamaica Bay and its watershed........ 32

Table 2-3. Selected disturbances of the Jamaica Bay social-ecological system .................. 33

Table 3-1. Historical timeline of critical human-system interactions in the Jamaica

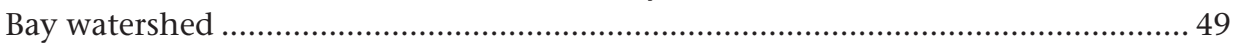

Table 3-2. Scale of "Jamaica Bay" represented in selected studies................................... 51

Table 3-3. People and institutions of Jamaica Bay represented in selected studies .......... 53

Table 3-4. Targets of resilience efforts as represented in selected studies......................... 54

Table 3-5. Characteristic disturbances as identified in the published Jamaica Bay

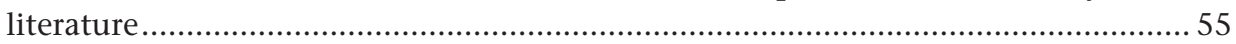

Table 4-1. A chronology of severe storms, 1635-2012 …......................................... 75

Table 5-1. Land cover change in the Jamaica Bay watershed, c. 1609, c. 1878, and 2014

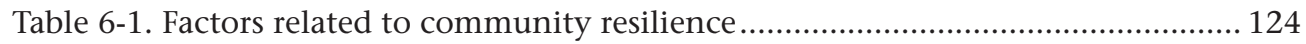

Table 8-1. Selected computational models applicable to Jamaica Bay ........................... 169

Table 9-1: Goals and services provided by green infrastructure systems built in

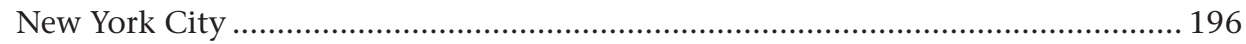

Table 9-2: Green infrastructure strategies to enhance resilience .................................... 210 



\section{Acknowledgments}

Like Jamaica Bay itself, this book is a testament to the powers of a resilient community.

The editors would like to thank the authors who contributed their time, energy, and wisdom to this book. Jamaica Bay's future and the practice of resilience depend on people being willing to work together and cross boundaries of discipline, institution, and experience. We appreciate their generosity, persistence, and patience as this book came together.

This book would not have happened without the efforts of Michael Dorsch. Michael was invaluable for providing technical assistance and editing of early drafts of several chapters and reviewing the text and references throughout the volume. He contributed enormously to getting this project off the ground and helping meet numerous deadlines. The editors also thank Peter Vancura for his efforts in providing technical assistance on research contributing to various chapters, including reviewing early drafts of project work and convening groups of authors. We also thank Jessice Fain, Mario Giampieri, and Chris Spagnoli for providing essential help with several of the figures in the book and Lesley Patrick, O. Douglas Price, and Sandra Clarke for logistical support.

The editors would also like to thank Bill Kornblum, John McLaughlin, and Bram Gunther for reading the entire manuscript and providing critical comments that improved many of the chapters.

The editors thank the team at Island Press. Courtney Lix, our editor, clarified our thinking and the text, provided many useful suggestions, and helped us keep the project on track. Sharis Simonian, the production editor, has been a firm hand on the tiller guiding the book to final publication. We also thank Chuck Savitt, Heather Boyer, Laurie Mazur, and David Miller at Island Press for supporting this project.

Finally, the editors wish to thank Nancy Kete and Sam Carter at the Rockefeller Foundation; the National Park Service; the City of New York; and Gillian Small, vice chancellor for research at the City University of New York, and Bill Tramontano, provost of Brooklyn College, for financial and institutional support of this project. Kate Ascher, Nerissa Moray, 
and Amelia Aboff of BuroHappold also provided critical support in starting the Science and Resilience Institute at Jamaica Bay. Without the support of all of these individuals, the institute and the book may never have materialized.

Eric Sanderson would like to thank John Robinson, Jon Dohlin, and Caleb McClennen at the Wildlife Conservation Society for supporting his participation. He also thanks Alison Sant and Darryl Young at the Summit Foundation for support. 